\title{
Cough tremor as presenting symptom of intraventricular tumor
}

品
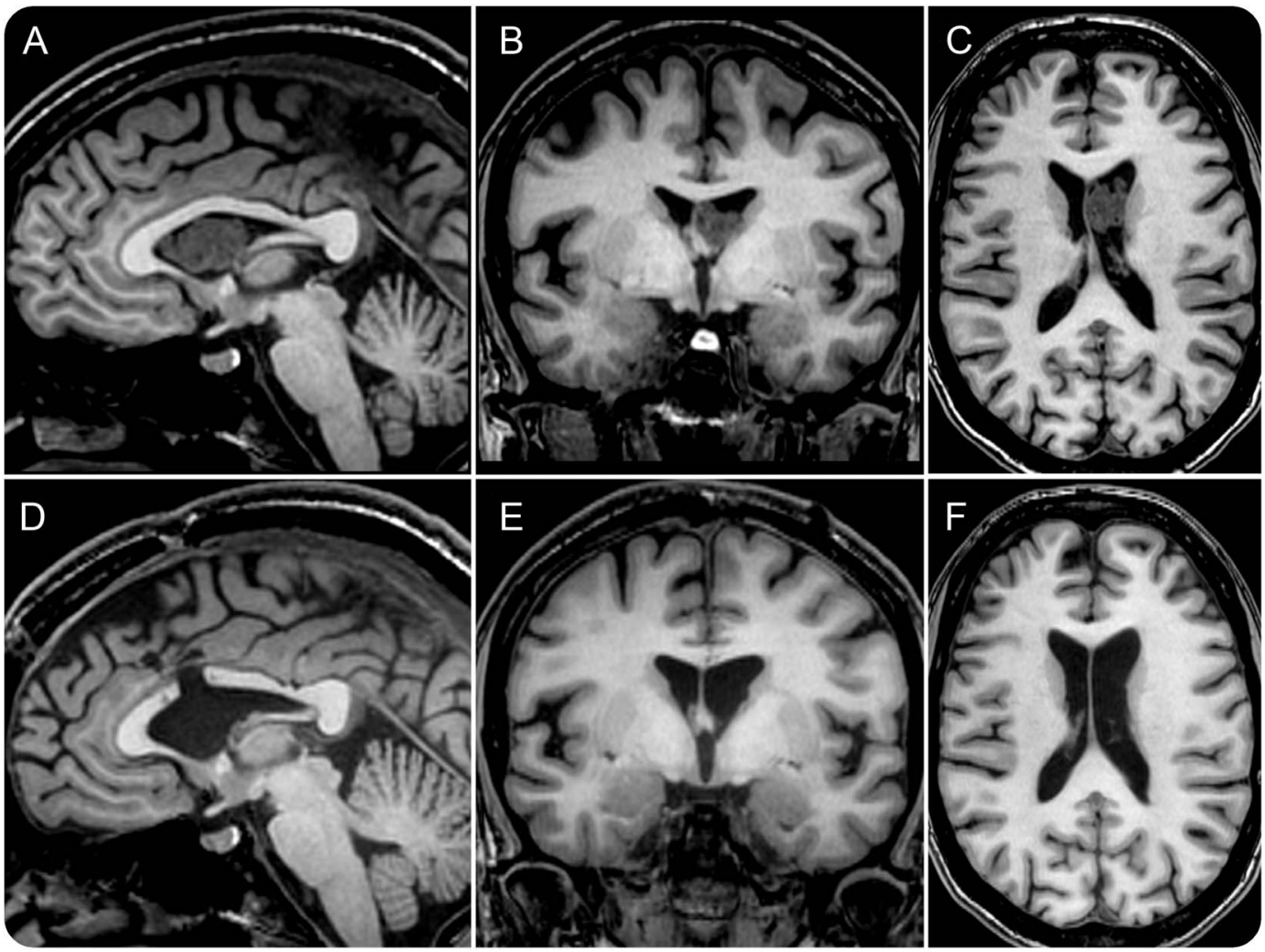

MRI shows intraventricular mass (A) and Monro foramen partial obstruction (B) leading to slight enlargement of left lateral ventricle (C). Coughing shifts the tumor, with complete obstruction to the free flow of CSF in the Monro foramen, causing intermittent hydrocephalus. Monro foramen obstruction disappeared after surgical removal of subependymoma (D-F).

A 39-year-old woman presented with right-hand tremor triggered by coughing. Her examination revealed tremor and irregular myoclonus at rest and transient right-hand tremor precipitated by coughing (video at Neurology.org). Brain MRI showed intraventricular tumor and partial foramen of Monro obstruction (figure). Intraventricular tumors in this location can cause sudden intermittent hydrocephalus, ${ }^{1}$ and focal thalamic lesions may cause hand tremor. ${ }^{2}$ We hypothesize that compression of the ventral intermediate nucleus of the thalamus caused by cough-induced hydrocephalus, with dysfunction of cerebello-thalamo-cortical circuit, may be the mechanism for cough-associated tremor of the contralateral hand; this disappeared after surgical removal of the subependymoma. Cough tremor may be associated with intraventricular tumors.

Maria Rosaria Mazza, MD, * Maurizio Morelli, MD, ${ }^{*}$ Michelangelo Gangemi, MD, Giulia Ferrigno, MD, Basilio Vescio, PhD, Luigi Maria Cavallo, MD, Aldo Quattrone, MD, Francesco Bono, MD

*These authors contributed equally to this work.

From the Institute of Neurology (Drs. Mazza, Morelli, Ferrigno, Quattrone, and Bono), Magna Græcia University of Catanzaro; Federico II University of Naples (Drs. Gangemi and Cavallo); and the Institute of Molecular Bioimaging and Physiology (Drs. Vescio, Quattrone, and Bono), National Research Council, Catanzaro, Italy.

Supplemental data at Neurology.org

Author contributions: Dr. Mazza: drafting/revising the manuscript, acquisition of data, and analysis/interpretation of data. Dr. Morelli: drafting/revising the manuscript, acquisition of data, and analysis/interpretation of data. Drs. Gangemi and Cavallo: surgical removal of 
tumor, analysis and interpretation of data. Dr. Ferrigno: analysis and acquisition of data. Dr. Vescio: analysis and acquisition of data. Prof. Quattrone: analysis and interpretation of data. Dr. Bono: study concept and design, drafting/revising the manuscript, analysis and interpretation of data.

Study funding: No targeted funding reported.

Disclosure: The authors report no disclosures relevant to the manuscript. Go to Neurology.org for full disclosures.

Correspondence to Dr. Bono: f.bono@unicz.it

1. Chittiboina P, Zhang S, Bao J, Vannemreddy P, Guthikonda B. Subpendymoma at the foramen of Monro presenting with intermittent hydrocephalus: case report and review of the literature. J La State Med Soc 2010;162:214-217.

2. Lehéricy S, Grand S, Pollak P, et al. Clinical characteristics and topography of lesions in movement disorders due to thalamic lesions. Neurology 2001;57:1055-1066.

\section{Save These Dates for AAN CME Opportunities!}

Mark these dates on your calendar for exciting continuing education conferences by the American Academy of Neurology. Learn more at AAN.com/conferences.

\section{Fall Conference}

- October 14-16, 2016, Las Vegas, NV, at the Cosmopolitan of Las Vegas

\section{Breakthroughs in Neurology}

- January 13-16, 2017, Phoenix, AZ, at the Sheraton Grand at Wild Horse Pass

\section{AAN Annual Meeting}

- April 22-28, 2017, Boston, MA, at the Boston Convention Center

\section{MACRA Changes How Neurologists Are Paid}

\section{What Is MACRA, and Why Is It Necessary?}

The Medicare Access and CHIP Reauthorization Act of 2015-MACRA-replaced the Medicare Sustainable Growth Rate formula for calculating physician payments. The rapidly rising costs of health care in the US are unsustainable. Changes in the health care system are essential and must happen now.

\section{How Will MACRA Affect Physician Payment?}

Our health care system is moving from "fee-for-service" payments to a wider array of "value-based" payment models that put the patient at the center of care by calling for the improvement of the quality, safety, and overall experience of patient care while demonstrating cost-effectiveness by providing care that is less expensive and delivers similar or improved clinical outcomes.

Learn more at $A A N . c o m / v i e w / M A C R A$. 


\section{Neurology}

Cough tremor as presenting symptom of intraventricular tumor

Maria Rosaria Mazza, Maurizio Morelli, Michelangelo Gangemi, et al.

Neurology 2016;87;1185-1186

DOI 10.1212/WNL.0000000000003100

This information is current as of September 12, 2016

$\begin{array}{ll}\begin{array}{l}\text { Updated Information \& } \\ \text { Services }\end{array} & \begin{array}{l}\text { including high resolution figures, can be found at: } \\ \text { http://n.neurology.org/content/87/11/1185.full }\end{array} \\ \text { Supplementary Material } & \begin{array}{l}\text { Supplementary material can be found at: } \\ \text { http://n.neurology.org/content/supp1/2016/09/12/WNL.0000000000003 } \\ 100 . D C 1\end{array} \\ & \begin{array}{l}\text { This article cites } 2 \text { articles, } 1 \text { of which you can access for free at: } \\ \text { http://n.neurology.org/content/87/11/1185.full\#ref-list-1 }\end{array} \\ \text { References } & \begin{array}{l}\text { Information about reproducing this article in parts (figures,tables) or in } \\ \text { its entirety can be found online at: } \\ \text { http://www.neurology.org/about/about_the_journal\#permissions }\end{array} \\ \text { Permissions \& Licensing } & \text { Information about ordering reprints can be found online: } \\ \text { http://n.neurology.org/subscribers/advertise }\end{array}$

Neurology ${ }^{\circledR}$ is the official journal of the American Academy of Neurology. Published continuously since 1951, it is now a weekly with 48 issues per year. Copyright @ 2016 American Academy of Neurology. All rights reserved. Print ISSN: 0028-3878. Online ISSN: 1526-632X.

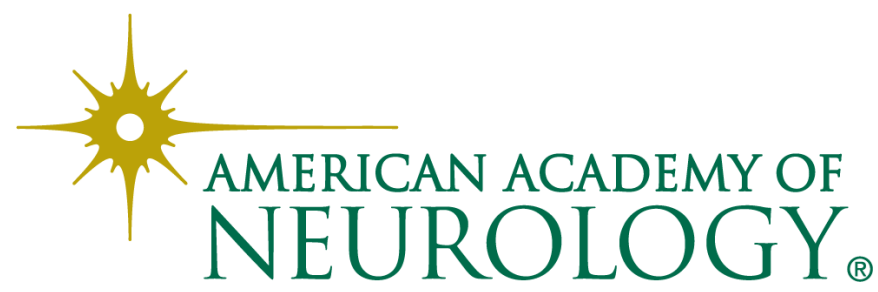

